\title{
Influence of Phototherapy on the Serum Lipids of Jaundiced Newborn Infants
}

\author{
EMMANUEL HADJIGEORGIOU, ${ }^{(51)}$ DEMETRA TRILIOURI, ANTONIA TRICHOPOULOU, \\ DIONISSIOS KASKARELLIS, AND DEMETRE NICOLOPOULOS \\ First Department of Obstetrics and Gynaecology, The Department of Biochemistry of Athens University and the \\ Neonatal Department of Alexandra Maternity Hospital, Athens, Greece
}

\begin{abstract}
Summary
The serum nonesterified fatty acids (NEFA), triglycerides, total cholesterol, lipid P, lysolecithin, sphingomyelin, lecithin, and phosphatidylethanolamine were determined on 15 full term and 13 premature jaundiced infants, before and after $48 \mathrm{hr}$ of phototherapy and compared to nonjaundiced matched control subjects.

The cholesterol levels of the jaundiced full term newborns were significantly higher than those of the healthy control full term infants. Differences were also observed before and after phototherapy between the jaundiced full term and the jaundiced premature infants in the serum lipid $P$ and sphingomyelin values, which were lower in the premature subjects. The serum triglycerides values of the jaundiced full term control infants were lower than those of the nonjaundiced newborns. A significant decrease of serum NEFA was observed after phototherapy in both the full term and premature groups of jaundiced infants.

The differences noted in cholesterol and lipid $P$ levels may be due to liver dysfunction because of the jaundice. The differences in NEFA levels before and after phototherapy can be caused by the photooxidative breaking up of the NEFA by the phototherapy, by the decreased absorption of NEFA, or the increased catabolism of lipids. The decreased synthesis of NEFA from ketone bodies and glucose, or the probability of binding of NEFA by the bilirubin during the phototherapy must also be considered.
\end{abstract}

\section{Speculation}

The higher serum cholesterol levels observed in the jaundiced infants could be due to hepatic damage (dysfunction or excretory impediment).

The differences in NEFA levels before and after phototherapy can be caused by the photooxidative breaking up of the NEFA by the phototherapy, by the decreased absorption of NEFA, or by the increased catabolism of lipids. The decreased synthesis of NEFA from ketone bodies and glucose, or the probability of binding of NEFA by the bilirubin during phototherapy must also be considered.

The effectiveness of phototherapy in the treatment of neonatal jaundice has been proved, but many questions about this form of treatment remain unanswered.

Recognized short term complications of phototherapy (15) include growth retardation (50), pyrexia, retinopathy (13), loose greenish stools, irritability, alteration of behavior (44), feeding difficulties, flea-bite rash, a tanning effect in Negro infants' skin (49), priapism, and the occasional case of the "bronze baby" (25) The long term consequences of phototherapy on intellectual and visual performance, recently reported by Drew et al. (15), are quite contrary to the findings of Teberg and Hodgman (47) and require further studies because of the many factors influencing the neuropsychologic development of neonate.

Increase in insensible water loss (34), peripheral blood flow, and heat loss (35), as well as an accelerated intestinal transit time (41), were observed in jaundiced neonates treated with phototherapy. Furthermore, a negative metabolic balance may be created because of increased needs and of reduced absorption (50). A temporary acidosis (24), a diminution in platelet life-span (29). and a suppression in biorhythms of blood glucose and calcium (38), as well as in secretion of luteinizing hormone, have been reported (9).

Odell et al. (33) and Blackburn et al. (4) reported an in vitro hemolysis when erythrocytes were irradiated with fluorescent light. The hemolysis is preceded by membrane damage, reflected by a loss of erythrocyte potassium and a reduction in membrane ATPase activity. Castro et al. (8), carrying out an investigation into the in vitro influence of light on the lipids of red cell membrane, found a significant increase of total lipids and cholesterol, lysolecithin, sphingomyelin, and saturated fatty acids. On the contrary, a decrease in lecithin, phosphatidyl serine and phosphatidylethanolamine was observed. The forementioned changes are considered to be the result of photooxidative process on the lipids of red cell membrane. It is interesting that Blackburn et al. (5) have not detected any effects of light on the red blood cells in vivo.

An in vivo investigation into the influence of phototherapy on the levels of serum lipids of jaundiced newborns was undertaken by us.

Review of the literature failed to reveal similar studies.

\section{MATERIALS AND METHODS}

The serum NEFA, triglycerides, total cholesterol, lipid P, lysolecithin, sphingomyelin, lecithin, and phosphatidylethanolamine were determined on 15 full term and 13 premature jaundiced infants before and after $48 \mathrm{hr}$ of phototherapy. The values after phototherapy were compared to 16 full term and 15 premature nonjaundiced controls subjects, matched for age and weight. The etiology of jaundice was not ascertained in most prematures and in the full term newborns it was mostly due to glucose-6-phosphate dehydrogenase deficiency. All the babies were healthy and no medication or fluid supplementation was given to them. The age range of jaundiced full term newborns was 2-5 days (mean 3.2), of the premature jaundiced newborns $2-6$ days (mean 2.9), of the control full term infants 3-6 days (mean 5), and of the control premature infants 3-6 days (mean 4.5 ).

The mean, of the highest for each infant, recorded total serum bilirubin values was $13.6 \mathrm{mg} / 100 \mathrm{ml}$ for the premature (range $12-16 \mathrm{mg} / 100 \mathrm{ml}$ ) and $16.9 \mathrm{mg} / 100 \mathrm{ml}$ for the full term infants (range $13-18.5 \mathrm{mg} / 100 \mathrm{ml}$ ). The feeding schedule and the powdered milk (Similac) formula administered were the same for all groups. The calories administered per $\mathrm{kg} / 24 \mathrm{hr}$ to the full term infants were $112.4 \pm 10$ for the jaundiced and $115 \pm 12$ for the control infants; to the premature infants were $95 \pm 15$ for the jaundiced and $93 \pm 12$ for the control infants. The ambient temperature was $30-32^{\circ}$ and the rectal temperature $36.8^{\circ} \pm 0.2^{\circ}$. 
In Table 1 the major data for the four groups of infants studied are presented. Venous blood was taken $2.5-3 \mathrm{hr}$ after the last feeding.

The colorimetric micromethod of Laurell and Tibbling (27), based on the formation of free fatty ester-Cu soaps, was developed for determining NEFA in $50 \mu \mathrm{l}$ plasma. Free fatty acids were extracted with chloroform-heptane-methanol. Silicic acid was used to eliminate interference by the phospholipids. Diphenylcarbozide was chosen for the colorimetric determination of $\mathrm{Cu}$.

For the cholesterol determination the rapid colorimetric technic of Ferro and Ham (17), a modification of the classic isopropyl alcohol extraction method, was used.

The assay for serum triglycerides was based on the use of an effective solvent extraction procedure, ethoxide transesterification, and color development with acetylacetone (Soloni (45)).

The determination of total lipids was carried out by applying the Folch (18) method, based on the extraction of lipids with chloroform-methanol solution and filtration using Whatman no 41 .

Bartlett's (3) method was used for the phospholipids, whereas the determination of different phospholipid fractions was based on a thin layer chromatography. The reliability of determination was confirmed by crossing with standard solution of total (Lyotrol, BD Merieux) and fractionized phospholipids (Sigma Co.).

The obtained values were corrected for hemoconcentration.

\section{RESULTS}

The obtained values, in coupling of comparable groups, was shown in Tables $2-5$.

The cholesterol levels of the jaundiced full term newborns before and after phototherapy were significantly higher than those

Table 1. Main data of studjed newborns (mean $\pm S E$ )

\begin{tabular}{|c|c|c|c|c|c|c|}
\hline & \multicolumn{4}{|c|}{ Phototherapy group } & \multicolumn{2}{|c|}{ Control group } \\
\hline & \multicolumn{2}{|c|}{ Prematures } & \multicolumn{2}{|c|}{ Full term } & \multirow[b]{2}{*}{ Prematures } & \multirow[b]{2}{*}{ Full term } \\
\hline & Before & After & Before & After & & \\
\hline No. of cases & 13 & & 15 & & 15 & 16 \\
\hline Males & 4 & & 9 & & 5 & 7 \\
\hline Females & 9 & & 6 & & 10 & 9 \\
\hline Gestational age (wks) & $33.15 \pm 0.31$ & $33.15 \pm 0.31$ & $39.4 \pm 0.34$ & $39.4 \pm 0.34$ & $34.8 \pm 0.50$ & $39.8 \pm 0.28$ \\
\hline Birth weight $(\mathrm{g})$ & $1647.6 \pm 44$ & $1537.6 \pm 42$ & $3242 \pm 119$ & $3150 \pm 95$ & $1.704 \pm 48$ & $1600 \pm 60$ \\
\hline Age (days) & $2.9 \pm 0.3$ & $4.9 \pm 0.3$ & $3.2 \pm 0.24$ & $4.53 \pm 0.34$ & $4.53 \pm 0.34$ & $5 \pm 0.40$ \\
\hline \multicolumn{7}{|l|}{ Etiology of jaundice } \\
\hline Unknown & 8 & & 5 & & & \\
\hline $\mathrm{ABO}$ incompatible & 3 & & 4 & & & \\
\hline Glucose-6-P dehydrogenase deficiency & 2 & & 6 & & & \\
\hline Bilirubin $(\mathrm{mg} / 100 \mathrm{ml})$ & $13.6 \pm 0.34$ & $10.4 \pm 0.14$ & $16.9 \pm 0.37$ & $11.2 \pm 0.60$ & & \\
\hline $\mathrm{Hb}(\mathrm{g})$ & $14.6 \pm 0.47$ & $13.9 \pm 0.44$ & $17 \pm 0.26$ & $14.9 \pm 0.28$ & $16.2 \pm 0.45$ & $16.4 \pm 0.33$ \\
\hline Het $(\%)$ & $42 \pm 1.3$ & $40.8 \pm 1.40$ & $51 \pm 1.1$ & $40.3 \pm 0.78$ & $44.6 \pm 1.64$ & $46.7 \pm 1.04$ \\
\hline Reticulocytes (\%) & $3.0 \pm 0.33$ & $1.16 \pm 0.30$ & $4.2 \pm 0.31$ & $2.17 \pm 0.33$ & $1.5 \pm 0.23$ & $1.4 \pm 0.26$ \\
\hline $\mathrm{Cal} / \mathrm{kg} / 24 \mathrm{hr}$ & $95 \pm 15$ & $95 \pm 15$ & $112.4 \pm 10$ & $112.4 \pm 10$ & $93 \pm 12$ & $115 \pm 12$ \\
\hline
\end{tabular}

Table 2. Comparison of results among full term infants (mean $\pm S E$ )

\begin{tabular}{|c|c|c|c|c|c|c|}
\hline & $\begin{array}{c}\text { Full term } \\
\text { before } \\
\text { phototherapy }\end{array}$ & $\begin{array}{c}\text { Full term } \\
\text { after } \\
\text { phototherapy }\end{array}$ & $t$ test & $\begin{array}{l}\text { Full term } \\
\text { controls }\end{array}$ & $\begin{array}{c}\text { Full tern } \\
\text { after } \\
\text { phototherapy }\end{array}$ & $t$ test \\
\hline Triglycerides, $\mathrm{mg} / 100 \mathrm{ml}$ & $84.7 \pm 9.4$ & $84.6 \pm 7.7$ & NS & $120.8 \pm 12.1$ & $84.6 \pm 7.7$ & $\mathrm{~S}(P<0.025)$ \\
\hline Cholesterol, mg/100 ml & $185.1 \pm 8$ & $167.8 \pm 6.3$ & NS & $116.2 \pm 7.1$ & $167.8 \pm 6.3$ & $\mathrm{~S}(P<0.001)$ \\
\hline NEFA, mEq/liter & $0.19 \pm 0.01$ & $0.095 \pm 0.007$ & $\mathrm{~S}(P<0.001)$ & $0.180 \pm 0.010$ & $0.095 \pm 0.007$ & $\mathrm{~S}(P<0.001)$ \\
\hline Lipid P, mg/100 ml & $7.02 \pm 0.21$ & $7.10 \pm 0.31$ & NS & $6.18 \pm 0.29$ & $7.10 \pm 0.31$ & $\mathrm{~S}(P<0.05)$ \\
\hline \multicolumn{7}{|l|}{ Phospholipids, mg/100 ml } \\
\hline Lysolecithin & $0.281 \pm 0.042$ & $0.38 \pm 0.05$ & NS & $0.31 \pm 0.05$ & $0.381 \pm 0.05$ & NS \\
\hline Sphingomyelin & $1.79 \pm 0.10$ & $1.77 \pm 0.15$ & NS & $1.35 \pm 0.10$ & $1.77 \pm 0.15$ & $\mathrm{~S}(P<0.05)$ \\
\hline Lecithin & $3.43 \pm 0.10$ & $3.51 \pm 0.13$ & NS & $2.98 \pm 0.12$ & $3.51 \pm 0.13$ & $\mathrm{~S}(P<0.001)$ \\
\hline Phosphatidylethanolamine & $0.28 \pm 0.04$ & $0.28 \pm 0.03$ & NS & $0.25 \pm 0.05$ & $0.28 \pm 0.03$ & NS \\
\hline
\end{tabular}

Table 3. Comparison of results among premature infants (mean $\pm S E$ )

\begin{tabular}{|c|c|c|c|c|c|c|}
\hline & $\begin{array}{c}\text { Prematures } \\
\text { before } \\
\text { phototherapy }\end{array}$ & $\begin{array}{c}\text { Prematures } \\
\text { after } \\
\text { phototherapy }\end{array}$ & $t$ test & $\begin{array}{c}\text { Premature } \\
\text { controls }\end{array}$ & $\begin{array}{c}\text { Prematures } \\
\text { after } \\
\text { phototherapy }\end{array}$ & $t$ test \\
\hline Triglycerides, $\mathrm{mg} / 100 \mathrm{ml}$ & $74.2 \pm 9$ & $73 \pm 8$ & NS & $91 \pm 10$ & $73 \pm 8$ & NS \\
\hline Cholesterol, mg/100 ml & $151 \pm 10.41$ & $145 \pm 5$ & NS & $134.8 \pm 12.7$ & $145 \pm 5$ & NS \\
\hline NEFA, mEq/liter & $0.171 \pm 0.01$ & $0.081 \pm 0.01$ & $\mathrm{~S}(P<0.001)$ & $0.180 \pm 0.012$ & $0.081 \pm 0.007$ & $\mathrm{~S}(P<0.001)$ \\
\hline Lipid $\mathrm{P}, \mathrm{mg} / 100 \mathrm{ml}$ & $5.71 \pm 0.27$ & $5.73 \pm 0.33$ & NS & $5.98 \pm 0.31$ & $5.73 \pm 0.33$ & NS \\
\hline \multicolumn{7}{|l|}{ Phospholipids, $\mathrm{mg} / 100 \mathrm{ml}$} \\
\hline Lysolecithin & $0.23 \pm 0.04$ & $0.32 \pm 0.06$ & NS & $0.33 \pm 0.06$ & $0.32 \pm 0.06$ & NS \\
\hline Sphingomyelin & $1.117 \pm 0.10$ & $1.267 \pm 0.13$ & NS & $1.26 \pm 0.13$ & $1.26 \pm 0.13$ & NS \\
\hline Lecithin & $3.112 \pm 0.16$ & $2.78 \pm 0.15$ & NS & $2.91 \pm 0.15$ & $2.78 \pm 0.15$ & NS \\
\hline Phosphatidylethanolamine & $0.184 \pm 0.03$ & $0.25 \pm 0.04$ & NS & $0.22 \pm 0.03$ & $0.25 \pm 0.04$ & NS \\
\hline
\end{tabular}


Table 4. Comparison of results between jaundiced full term and premature infants before phototherapy (mean $\pm S E)$

\begin{tabular}{lccl} 
& Full term & Prematures & \multicolumn{1}{c}{ test } \\
\hline Triglycerides. $\mathrm{mg} / 100 \mathrm{ml}$ & $84.7 \pm 9.4$ & $74.2 \pm 9$ & $\mathrm{NS}$ \\
Cholesterol. $\mathrm{mg} / 100 \mathrm{ml}$ & $185.1 \pm 8$ & $151 \pm 10.41$ & $\mathrm{~S}(P<0.05)$ \\
NEFA. mEq/liter & $0.189 \pm 0.01$ & $0.171 \pm 0.01$ & $\mathrm{NS}$ \\
Lipid P. $\mathrm{mg} / 100 \mathrm{ml}$ & $7.02 \pm 0.21$ & $5.71 \pm 0.27$ & $\mathrm{~S}(P<0.001)$ \\
Phospholipids. $\mathrm{mg} / 100 \mathrm{ml}$ & & & $\mathrm{NS}$ \\
$\quad$ Lysolecithin & $0.281 \pm 0.04$ & $0.23 \pm 0.04$ & $\mathrm{~S}(P<0.05)$ \\
Sphingomyelin & $1.79 \pm 0.10$ & $1.117 \pm 0.10$ & $\mathrm{NS}$ \\
Lecithin & $3.43 \pm 0.10$ & $3.112 \pm 0.16$ & $\mathrm{NS}$ \\
Phosphatidylethanolamine & $0.28 \pm 0.04$ & $0.184 \pm 0.003$ & \\
\hline
\end{tabular}

Table 5. Comparison of results between jaundiced full term and premature infants after phototherapy (mean $\pm S E$ )

\begin{tabular}{lccc}
\hline & Full term & Prematures & $t$ test \\
\hline Triglycerides, $\mathrm{mg} / 100 \mathrm{ml}$ & $84.6 \pm 7.7$ & $73.0 \pm 8$ & $\mathrm{NS}$ \\
Cholesterol, $\mathrm{mg} / 100 \mathrm{ml}$ & $167.8 \pm 6.3$ & $145 \pm 5$ & $\mathrm{~S}(P<0.025)$ \\
NEFA, $\mathrm{mEq} / \mathrm{liter}$ & $0.095 \pm 0.007$ & $0.081 \pm 0.01$ & $\mathrm{NS}$ \\
Lipid P. $\mathrm{mg} / 100 \mathrm{ml}$ & $7.11 \pm 0.31$ & $5.73 \pm 0.33$ & $\mathrm{~S}(P<0.001)$ \\
Phospholipids, $\mathrm{mg} / 100 \mathrm{ml}$ & & & $\mathrm{NS}$ \\
$\quad$ Lysolecithin & $0.381 \pm 0.05$ & $0.32 \pm 0.06$ & $\mathrm{~S}(P<0.025)$ \\
Sphingomyelin & $1.77 \pm 0.15$ & $1.267 \pm 0.13$ & $\mathrm{NS}$ \\
$\quad$ Lecithin & $3.51 \pm 0.13$ & $2.78 \pm 0.15$ & $\mathrm{NS}$ \\
Phosphatidylethanolamine & $0.28 \pm 0.03$ & $0.25 \pm 0.04$ & \\
\hline
\end{tabular}

of the healthy control full term infants $(P<0.001)$. Probably significant differences $(P<0.05$ and $P<0.025)$ were observed before and after phototherapy between the jaundiced full term and the jaundiced premature infants in their serum total cholesterol, which was lower in the prematures. Differences were also observed before any phototherapy between the jaundiced full term and the jaundiced premature infants in the serum lipid $P$ and sphingomyelin values, which were lower in the prematures. These differences continued to exist after the phototherapy.

The serum triglyceride values of the nonjaundiced full term control infants were higher than those of the jaundiced full term newborns $(P<0.025)$, whereas their lipid $P$, sphingomyelin, and lecithin values were lower (Table 2 ).

A significant decrease $(P<0.001)$ of serum NEFA was observed after phototherapy in both the full term and premature groups of jaundiced infants.

\section{DISCUSSION}

The differences noted in the different lipid fraction of the serum can be explained by factors connected with the hemolytic process of jaundice, and/or the phototherapy (photooxygenative, photooxidative?) process (32).

The higher serum total cholesterol levels observed in the jaundiced full term infants and the similarly higher lipid $\mathrm{P}$ content in the same group of infants, compared to the healthy control subjects, could be due to hepatic damage (dysfunction or excretory impediment). A slight elevation of the plasma enzyme activities in jaundiced infants has been described previously (26) and can be considered the result of mild hepatic damage, associated with hyperbilirubinemia. Recently, Orzalesi et al. (36), in a study of plasma enzyme levels, namely, glutamate oxalacetate transaminase, glutamate pyruvate transaminase, alkaline phosphatase, lactate dehydrogenase, leucine aminopeptidase, and sorbitol dehydrogenase, failed to provide any evidence that phototherapy has a direct toxic effect on the liver cells of human newborns. On the other hand, the higher concentration of cholesterol in the jaundiced subjects may be due, in part, to the correspondingly higher concentration of bilirubin which could interfere in the colorimetric estimation of cholesterol. However, this difference, at least among the full term infants, was too large to be accounted for by the methodologic consideration, since the artifactual increase of cholesterol concentration is rarely more than $25 \%$, even when bilirubin concentration is more than $10 \mathrm{mg} / 100 \mathrm{ml}$. This is suggested in the literature, but it was also shown in experiments in our laboratory where the Ferro and Ham method (16) was compared with the more reliable method employing the $\mathrm{FeCl}_{3}-\mathrm{H}_{2} \mathrm{SO}_{4}$ reaction (Henry, R. J., Clinical Chemistry, Harper and Row, New York, 1966) in 20 cholesterol determinations in jaundiced sera (9.2-13 $\mathrm{mg} / 100 \mathrm{ml}$ bilirubin) and 20 determinations of serum from normal newborns: the mean values from the normal newborns were 246 $\mathrm{mg} / 100 \mathrm{ml}$ with the Ferro-Ham method vs. $193 \mathrm{mg} / 100 \mathrm{ml}$ with the $\mathrm{FeCl}_{3}-\mathrm{H}_{2} \mathrm{SO}_{4}$ reaction; i.e., the former method gave 1.27 times higher values. For the jaundiced sera the Ferro-Ham method gave mean values of $190 \mathrm{mg} / 100 \mathrm{ml}$ vs. $122 \mathrm{mg} / 100 \mathrm{ml}$ of the $\mathrm{FeCl}_{3^{-}}$ $\mathrm{H}_{2} \mathrm{SO}_{4}$ reaction. The coefficient of 1.56 of higher values of jaundiced sera for cholesterol (compared to 1.27 for the nonjaundiced sera) cannot account for the observed increase of serum cholesterol concentrations in the jaundiced infants.

Before arriving to definite conclusions, more detailed studies of the synthesis, intrahepatic transfer and catabolism of cholesterol, lipids, lipoproteins, and bile salts in the jaundiced newborns are needed. The observed lower serum levels of triglycerides in the full term jaundiced infants could be due to a defective digestion of lipids in the intestine because of increased gastrointestinal motility.

The observed significant $(P<0.001)$ decrease of NEFA after phototherapy in both full term and premature infants could be explained in many ways; some of these are as follows.

1. This can be explained in a direct way by photo-oxidative or photooxygenative breaking up of the NEFA. by phototherapy. Ostrea et al. (37) have shown in vitro a probable photooxidative influence of phototherapy on NEFA. Doleiden et al. (14) have proved in vitro that singlet oxygen, by which phototherapy may exert its photooxygenative effect (31), decreases the cholesterol and fatty acids levels by photoperoxidation.

2. It can be explained indirectly, by the decreased absorption of NEFA caused by some enzyme deficiency or inhibition in a similar way, as that observed during phototherapy for lactase by Bakken (1) and for intestinal disaccharidase of the rat by Dinari et al. (11). It is also known that phototherapy increases intestinal peristalsis (41).

3. An increase of bile salts into the lumen could explain the increased intestinal peristalsis (16) after phototherapy, as well as the decreased absorption of NEFA (10).

4. An increased catabolism of lipid during phototherapy in order to compensate for a negative metabolic balance could be an explanation. A catabolic state of the infants undergoing photo- 
therapy is speculated from their increased water loss from the skin (34).

5. It can be explained by the decreased synthesis of NEFA from ketone bodies and glucose. The results of Sisson et al. (43) and Gromisch et al. (22), who have found a decrease of vitamin $\mathrm{B}_{2}$ in phototherapy-treated infants, and the observed differences in urinary tryptophan excretion after phototherapy by Rubatelli et al. (40) corroborate this supposition. Moreover, it is known that nicotinic acid, a metabolic byproduct of tryptophan, inhibits cholesterol synthesis and lowers the plasma lipoproteins concentration $(2,28,39)$.

6 . The decrease in NEFA may come about by promoting the incorporation of fatty acids containing photosensitive groups into phospholipids of cell membrane, in order to protect it from photolysis. Greenberg et al. (21) have shown that incorporation in Escherichia coli.

7. The binding of NEFA by the bilirubin during the phototherapy would result in a decrease. The detected pigment in the bronze baby syndrome coincides with a protein-free complex of unconjugated bilirubin with certain fatty acids and cell membrane phospholipids (20). On the other hand, Jirsa and Sedlacek (23) and Brodersen et al. (7) observed the formation of easily sedimenting macromolecular complexes of indirect bilirubin and NEFA when bilirubin levels exceeded the binding capacity of albumins. However, the last effect of phototherapy on NEFA must be rejected; if this way of action were true, an increased incidence of kernicterus after phototherapy should be expected.

In vitro metabolic studies, using skin and fatty tissue specimens from jaundiced and nonjaundiced newborns and subjecting the specimens to phototherapy, would be very helpful in ascertaining which of the above mechanisms causes the NEFA decrease after phototherapy. The overall rate of bilirubin photooxygenation is influenced by the concentration of molecular oxygen in the surrounding (6) medium. Since oxygen is far more soluble in nonpolar and lipophilic media than in water, it is likely that bilirubin associated with lipoprotein and lipids in the skin and fatty tissues will undergo photooxygenation more readily than bilirubin in the serum (42). This effect will be magnified, of course, by the fact that serum bilirubin gets less exposure to light than the extravascular pigment fraction at or near the irradiated surface.

The clinical significance of the observed temporary serum NEFA decrease after phototherapy remains open to hypotheses. NEFA participation in cell membrane and prostaglandin synthesis and their role in the photometabolic processes make their study the more interesting. Maurer et al. (30) have recently observed that a 2-hr period of exposure of platelets to blue fluorescent light phototherapy caused a significant injury; exposed platelets would not aggregate, were depleted of adenine nucleotides and glycogen, and on electron microscopy showed a loss of glycogen granules and organelles plus ill defined external membranes. These platelets lost their ability to aggregate. It is interesting that a similar loss of ability of platelets to aggregate was observed by Friedman et al. (19) on six parenterally fed neonates with diminished levels of NEFA. This platelet dysfunction was normalized when the serum NEFA levels returned to normal. The probability of a relation between the decreased levels of NEFA and the injury of platelets, both noted after phototherapy, remains open to speculation and, possibly, future investigation.

Finally, it would also be interesting to study the possible influence of vitamin $\mathrm{E}$ on the photometabolic process of bilirubin and lipids, as vitamin $E$ is a biologic antioxidant, a stabilizer of polyunsaturated fatty acids (48) and, through a complex link with glutathione peroxidase and selenium $(12,46)$, contributes to the integrity of cell membranes.

\section{REFERENCES AND NOTES}

1. Bakken. A. F.: Intestinal lactase deficiency as a factor in the diarrhoea of lighttreated jaundiced infants. N. Engl. J. Med., 294(11): 615 (1976).

2. Bacter. P. J., and Connor. W. E.: The transport of triglyceride in the high-density lipoproteins of human plasma. J. Lab. Clin. Med.. 85: 260 (1975).
3. Bartlett. G. R.: Phosphorus assay in column chromatography, J. Biol. Chem. 2.34: $466(1959)$.

4. Blackburn. M. G.. Orzalesi. M. M.. and Pigram. P.: Effect of light and hiliruhin on fetal red blood cells in vitro. Biol. Neonate, 21: 35 (1972).

5. Blackburn. M. G.. Orzalesi. M. M.. and Pigram. P.: Effect of light on fetal red blood cells in vivo. J. Pediat. sit): $64($ (1972).

6. Bonnett. R., and Stewart. J. C. M.: Singlet oxygen in the photouxidation of bilirubin in hydroxylic solvents. Biochem. J.. $1301985(1970)$.

7. Brodersen. R.. Funding. L.. Pedersen. A. O.. and Rigaard-Petersen. H.: Binding of hilirubin to low aftinity sites of human serum albumin in vitro lollowed hy co-cristallization. Scand. J. Chin. Lab. Invest.. 2\%: 433 (1972).

8. Castro. M.. Tambucci. S. G.. Panero. A.. Gardini. O.. and Orzalesi. M.: Studio in vitro degli effetti della luce sui lipidi del globulo ronso. Minerva Pediat.. 2.8 $391(1976)$.

9. Dacou-Voutetakis. C.. and Anagnostakis. D.: Phototherapy and serum I.H levels in newborns [Abstr.]. Pediat. Res., 10:876 (1976).

10. Dawson. A. M.. and Saunders. D. R.: In: W. Taylor: The Biliary System. P. 1,3 (Blackwell. Oxford. 1965).

11. Dinari. G.. Daum. F., Cohen. M. I.. and McNamara. H.: Effect of phototherapy on intestinal disaccharidase activity in the rat [Abstr.]. Pediat. Res.. 11: 443 (1977).

12. Diplock. A. T.. and Lucy. J. A.: The biochemical modes of action of vitamin I and selenium: A hypothesis. FEBS Lett. 29: 205 (1973).

13. Dobson. V.. Cowett. R. M.. and Riggs. L. A.: Long-term effect of phototherapy on visual function. J. Pediat. s6: 555 (1975).

14. Doleiden, E. H.. Fahrenholtz. S. R.. Lamola, A. A. and Tromolo. A. M Reactivity of cholesterol and some fatty acids touard singlet oxvgen. Photochem. Photobiol., 2(): 519 (1974).

15. Drew. J. H. Marriage. K. J.. Bayle. V. V.. Bajrazewski. E.. and Mciamara. J M.: Phototherapy: Short and long-term complications. Arch. Dis. Childhood. 51: 454 (1976).

16. Editorial: Bile salts as purgatives. Lancet. $i: 1141$ (1977)

17. Ferro, P. V.. and Ham. A. B.: Rapid determination of total and free cholesterol in serum. Amer. J. Clin. Pathol., 33: 545 (1960).

18. Folch. J.. Lees. M.. and Sloane-Stanley, G. H.: A simple method for the inolation and purification of total lipids from animal tissues. J. Biol. (hem.. 2.2): 497 (1957).

19. Friedman. Z., Lamberth. E.. Seyberth. H., and Oates, J.: Essential fatty acid deficiency platelet aggregation and the major urinary metabolites of the $L$ prostaglandins (PGE-M) in the newborn [Abstr.]. Pediat. Res.. 10: 354 (1976).

20. Gartner. L. M. and Lee. K. S.: Bilirubin binding. free fatty acids and a new concept for the pathogenesis of kernicterus. In: D. Bergsma and S. H. Blondheim: Bilirubin metabolism in the newborn (II). Birth Defects. Original Article Series. Vol. XII. No. 2. pp. 264 (Williams \& Wilkins. Baltimore. 1976).

21. Greenberg. G. R. Chakrabatti, D and Khorana. H. G.: Incorporation of fatt acids containing photosensitive groups into phospholipids of Escherichis coli. Biochemistry, 18: $86(1976)$

22. Gromisch. D. S.. Lopez. R.. Cole. H. S., and Cooperman. J. M.: Light (phototherapy) induced riboflavin deficiency in the neonate. J. Pediat.. 9(1): 118 $(1977)$.

23. Jirsa, M., and Sedlacek. B.: Aggregation von Bilirubinteilchen in ststem Losungmittel-Fallungsmittel. Coll. Czec. Chem. Commun.. 21: 41)9 (1955).

24. Kirkpatric, B. V.. Stoerner. J. W.. Hunter. C. R.. and Maurer. H. M.: Effect of phototherapy on acid-base balance in low birth weight infants [A hstr.]. Pediat. Res.. 10: 428 (1976).

25. Kopelman, A. E., Brown. R. S.. and Odell. G. B.: The bronze baby syndrome: A complication of phototherapy. J. Pediatr.. 8/: 466 (1972).

26. Lapi, A. S.. Schwarzenberg. T. L., and Mancini. G.: Uheriore contributo alla conoscenza dell enzimogramma plasmatico nellittero grave del neonato. Pediat. Intern.. 18: 473 (1968).

27. Laurell. S., and Tibbling. G.: Colorimetric microdetermination of free fatty acids in plasma. Clin. Chim. Acta. 16:56(1967)

28. Magide. A. A.. and Myant. N. B.: Loss of cholesterol from muscle and skin of monkeys treated with nicotinic acid. Atherosclerosis. 21: 273 (1975).

29. Maurer. M. H.. Fratkin. M.. McWilliams, N. B., Kirkpatrick. B.. Draper. D. Haggins. J. C.. and Hunter. C. R.: Effects of phototherapy on platelet counts in low-birth weight infants and on platelet production and life span in rabbits. Pediatrics, 57: 506 (1976).

30. Maurer. H. M.. Haggins. J. C., and Still. W. J. S.: Platelet injury during phototherapy. Amer. J. Hematol.. I: 103 (1976).

31. McDonagh. A. F.: The role of singlet oxvgen in bilirubin photooxidation. Biochem. Biophys. Res. Commun.. 44:1306 (1971).

32. McDonagh, A. F.: Photochemistry and photometabolism of bilirubin IXa. In: D. Bergsma and S. H. Blondheim: Bilirubin Metabolism in the Newborn. Birth Defects, Original Article Series, Vol. XII, No. 2. p. 264 (Williams \& Wilkins. Baltimore. 1976).

33. Odell. G. B., Brown, R. S., and Kopelman. A. E.: The photodynamic action of bilirubin on erythrocytes. J. Pediat. 81: 473 (1972)

34. Oh, W., and Karecki. H.: Phototherapy and insensible water loss in newborn infants. Amer. J. Dis. Child.. 124: 230 (1972).

35. Oh, W., Yao, A. C., Hanson, J. S., and Lind, J.: Peripheral circulatory response to phototherapy in newborn infants. Acta Paediat. Scand., 62: 49 (1973).

36. Orzalesi, M., Natoli. G.. Panero, A., and Ciocca. M.: Plasma hepatic enzymes in jaundiced newborn infants treated with phototherapy. In: D. Bergima and S. H. Blondheim: Bilirubin Metabolism in the Newborn (II). Birth Defects Original Article Series, Vol. XII. No. 2. p. 93 (Williams \& Wilkins, Baltimore. 1976) 
37. Ostrea, E. M., Ting, E. L., and Gwisdalla, C. A.: Photooxidation of essential fatty acids: A possible complication of phototherapy [Abstr.]. Pediat. Res., 10: 429 (1976).

38. Park, T. S., Padget, S., Fiorentino, T., Root, A. W., and Sisson, T. R. C.: Effect of phototherapy and nursery light on neonatal biorhythms [Abstr.]. Pediat. Res.. 10: 429 (1976)

39. Raja. P. K., and Jarowski, C. I.: Utility of fasting essential amino acid plasma levels in formulation of nutritionally adequate diets. IV. Lowering of human plasma cholesterol and triglyceride levels by lysine and tryptophan supplementation. J. Pharmaceut. Sci., 64: 69l (1975).

40. Rubaltelli, E. F., and Allegri, G., Gosta, C.. and De Antoni, A.: Urinary excretion of tryptophan metabolites during phototherapy. J. Pediat.. 85: 865 (1974).

41. Rubaltelli, E. F., and Largajolli, G.: Effect of light exposure on gut transit time in jaundiced newborns. Acta Paediat. Scand., 62: 146 (1973).

42. Sargent, J. W., and Sefl, R. J.: Properties of perfluorinated liquids. Fed. Proc., 29: 1699 (1970).

43. Sisson, T. R. C., Slaven, B., and Hamilton, P. B.: Effect of broad and narrow spectrum fluorescent light on blood constituents. In: D. Bergsma and S. H Blondheim: Bilirubin Metabolism in the Newborn (II). Birth Defects, Original Article Series, Vol. XII, No. 2, p. 122 (Williams \& Wilkins, Baltimore, 1976).
44. Snyder, D. M., Telzrow, H., Tronick, E., and Brazelton, T. B.: Effects of phototherapy on neonatal behavior [Abstr.]. Pediat. Res., 10: 432 (1976).

45. Soloni, F. G.: Simplified micromethod for determination of serum triglycerides. Clin. Chem., 17: 529 (1971)

46. Tapel, A. L.: Selenium-glutathione peroxidase and vitamin E. Amer. J. Clin. Nutr., 27: 960 (1974).

47. Teberg, A., and Hodgman, J. E.: Effect of phototherapy in low birth weight infants on growth and development at 2 years [Abstr.]. Clin. Res., 19: 224 (1971).

48. Witting. L. A.: Vitamin E-polyunsaturated lipid relationship in diet and tissues Amer. J. Clin. Nutr, 27: 952 (1974).

49. Woody, N. C., and Brodkey, M. J.: Tanning from phototherapy for neonatal jaundice. J. Pediat., 82: 1042 (1973).

50. Wu, P. Y. K., Lin, R. C., Hodgman, J. E., Kokosky, M. J., and Teberg, A. J. Effect of phototherapy in preterm infants on growth in the neonatal period. J. Pediat., 85: 563 (1974).

51. Requests for reprints should be addressed to: Dr. Emmanuel Hadjigeorgiou Alexandra Maternity Hospital, 80 Vass. Sophia's Ave., Athens 611 (Greece) 52. Received for publication October 22, 1976.

53. Accepted for publication September 28,1977 